\title{
Med hodet i sanden kommer vi ingen vei
}

Rune Bjerke er Arbeiderparti-politiker, vellykket næringslivsleder og nær venn av statsminister Jens Stoltenberg. Men nå kan han ha lagt seg ut med den rødgrønne regjeringen - eller iallfall deler av den. I hovedtalen på Finansnæringens dag i slutten av mars i år trakk han frem private helseforsikringer som et satsingsområde for forsikringsbransjen: «Vi ser at etterspørselen etter helseforsikringer nær sagt eksploderer.» Nesten ti ganger så mange har privat helseforsikring $\mathrm{i}$ dag som i 2003 - 34000 i 2003, 300000 ved utgangen av 2011. 90\% av forsikringene selges via arbeidsgiver. Bjerke ser på økt salg av helseforsikringer som noe nær en vinn-vinn-situasjon - inntekt til forsikringsselskapene og besparelser for arbeidsgivere og arbeidstakere.

Bjerkes uttalelser har fått noen til å se rødt. SV-leder Audun Lysbakken sier til Klassekampen at han «hadde forventet bedre av Rune Bjerke. Det er noe lite hederlig ved å skape seg markeder gjennom å lage falske skremselsbilder av norsk helsevesen» (1). Han uttaler videre at den sterke veksten i de private helseforsikringene er en trussel mot den norske velferdsstaten. Senterpartiets helsepolitiske talsperson, Kjersti Toppe, reagerer også sterkt «på at Rune Bjerke går ut på denne måten. Det er utidig. (...) Problemet er at dette slår en kile inn i det offentlige helsevesenet ... Han burde tenke litt på sitt samfunnsansvar» (1).

Den som har hørt Bjerkes tale (vi som ikke var til stede kan høre den i sin helhet på nettsidene til Finansnæringens Fellesorganisasjon) (2), forstår at han ikke har vansker med å ha to tanker i hodet på én gang. Bjerke er naturligvis klar over at det han sier kan være politisk kontroversielt. Samtidig har han en jobb å gjøre der han er: «Vi som bransje skal selvfølgelig være opptatt av norsk helsepolitikk, men vi må også være opptatt av å tilby produkter som er etterspurt, og som også sørger for at Bedrifts-Norge når sine mål. Og et av de aller, aller viktigste målene for Bedrifts-Norge er faktisk å ha arbeidstakerne til stede på jobben,» sa han og viste til at Moelven Industrier mener de har spart sine ansatte for 275 år i helsekø og det offentlige for store utgifter gjennom å ha kjøpt privat helseforsikring for sine 3200 ansatte siden 2007 (2). Dette må da være bra både for pasienter, samfunnet og næringslivet?

Både Lysbakken, Toppe og Bjerke har rett. Hvis andelen av befolkningen som ønsker private helseforsikringer fortsetter å vokse i samme takt som den har gjort de siste ti årene, truer det den offentlige helsetjenesten i Norge slik vi kjenner den i dag. Det har bekymret mange i lang tid og har også vært drøftet på lederplass her i Tidsskriftet $(3,4)$. Samtidig er selvsagt det aller viktigste for helsetjenesten å gi dem som trenger det hjelp - og få dem friske så raskt som mulig. Private helseforsikringer kan være en trussel mot en offentlig helsetjeneste utelukkende finansiert over skatteseddelen, men å angripe Rune Bjerke er å skyte på pianisten. Han gjør bare jobben sin ved å tilby produkter som er etterspurt. For hvem av oss ønsker ikke en garanti slik den Storebrand Forsikring kommer med (5): «Behandling når du trenger det. Garantert time innen 14 virkedager. Tilgang til vårt unike nettverk av legespesialister i Norden og Europa. Mulighet for «second opinion» - ny medisinsk vurdering av diagnose ved alvorlig lidelse. Forsikringen dekker alt fra en enkel time hos fysioterapeut til kreftbehandling. Du betaler ingen egenandeler.» Det er vel sant å si dette vi forventer at vårt offentlige helsevesen skal tilby?

Spørsmålet er hvorfor det er så stor og økende etterspørsel etter tilbud og tjenester vi tilsynelatende allerede har. Er de som kjøper forsikringene dumme? Driver forsikringsselskapene skremselspropaganda? Eller kan det rett og slett være at den norske helsetjenesten ikke er fullt så god og tilgjengelig for alle som vi liker å tro, og at det derfor kan være fornuftig å tegne en privat tilleggsforsikring hvis man har anledning? En lang rekke bekymringsmeldinger fra pasienter og helsepersonell de siste årene kan tyde på det. Og når assisterende direktør i Helsetilsynet Geir Sverre Braut nylig fant det nødvendig å skrive en kronikk i Aftenposten om sin uro for sviktende profesjonalitet og mangelfull faglighet $i$ styringen av tjenestetilbudet i HelseNorge (6) og samme avis for få dager siden meldte om uakseptabel ventetid på nødvendig palliativ strålebehandling for alvorlig syke kreftpasienter (7), er det iallfall grunn til å stille spørsmålet.

Ingen land har trylleformelen som kan gi alle innbyggere all den helsetjeneste de ønsker seg. Den ubehagelige sannhet er at det må være en eller annen form for prioritering eller begrensning enten av hvilke tjenester som skal tilbys eller av hvem som skal få dem. Helsedirektør Bjørn-Inge Larsen har gang på gang tatt til orde for mer eksplisitt prioritering og rasjonering av helsetjenestene. Han får mye ros for å ha tatt opp dette vanskelige spørsmålet, slik også Inge Lønning fikk da han som leder for to offentlige utredninger i henholdsvis 1987 og 1997 la grunnlaget for prioriteringsdebatten i Norge. Men ingen ønsker å være den som sier nei. Den andre muligheten er å ha et basistilbud fra det offentlige og la dem som ønsker det betale ekstra for helsetjenester enten direkte eller gjennom private helseforsikringer. Da settes likhetsidealet til side.

Uansett må vi velge: Enten et helsevesen der alle behandles likt, men der vi ikke kan få alt vi ønsker, eller et to- eller flerdelt helsevesen, der noen betaler og får mer enn andre. Vi er allerede på god vei dit. Å stikke hodet i sanden og late som om problemet ikke eksisterer og at alle kan få alt, løser ingenting.

\section{Litteratur}

1. Ekeberg E. Får refs for helseutspill. Klassekampen 30.4.2012

2. www.fnh.no/no/Hoved/Aktuelt/Finansnaringens-dag-2012---presentasjoner/ (8.5.2012)

Haug C. Helseministerens forsikringer. Tidsskr Nor Lægeforen 2002: 122: 2689.

4. Haug C. Med liten skrift. Tidsskr Nor Lægeforen 2003; 123: 2007.

. Helseforsikring - garantert rask behandling. www.storebrand.no/site/stb.nsf/ Pages/helseforsikring.html (8.5.2012).

6. Hjeltnes B, Braut GS. Helsetjenesten mangler dirigenter. Aftenposten. 20.4.2012

7. Dommerud T. Må vente ukevis på strålebehandling. Aftenposten. 6.5.2012. 